\title{
Description of the Anxiety Level of Pregnant Women Regarding Antenatal Care Services During The COVID-19 Pandemic: Literature Review
}

\author{
Lilis Nur Rahmah Fauziyah ${ }^{1}$, Budi Prasetyo ${ }^{2 *}$, Arief Bakhtiar ${ }^{3}$ \\ ${ }^{1}$ Departement of Midwifery Education, Faculty of Medicine, Universitas Airlangga 60132, Surabaya, East Java- Indonesia \\ ${ }^{2}$ Departement of Obstetrics and Gynecology, Faculty of Medicine, Universitas Airlangga 60132, Surabaya, East Java - Indonesia \\ ${ }^{3}$ Departement of Pulmonology and Respiratory Medicine, Faculty of Medicine, Universitas Airlangga, Surabaya 60132, East Java - \\ Indonesia \\ Corresponding Author: budi-p@fk.unair.ac.id
}

\begin{abstract}
Background: Anxiety of pregnant women increases during the COVID-19 pandemic. Pregnancy accompanied by anxiety will lower the mother's immune system so that pregnant women will be more susceptible to being infected with COVID-19. Pregnant women are placed into a vulnerable group, so they need careful monitoring of their health. The provision of maternal services during a pandemic needs to be a concern to avoid an increase in maternal morbidity and mortality. This study aims to describe the level of anxiety of pregnant women towards Antenatal Care visits during the COVID-19 pandemic. Methods: Literature review through searching scientific publications for the 2019-2021 period using several databases, namely Pubmed, Science Direct, and Google Scholar. Results: 5 articles were collected and discussed in the literature review after meeting the inclusion and exclusion criteria. The literature results are $\mathrm{N}=14$, Pubmed=5, Science Direct=3, Google Scholar=6. Conclusion: The majority of pregnant women experience mild anxiety. The COVID-19 pandemic has increased anxiety among pregnant women. There is a relationship between the level of anxiety of pregnant women and Antenatal Care visits to health care facilities during the COVID-19 pandemic.
\end{abstract}

Keyword: Anxiety Level, Antenatal Care, COVID-19

\section{Introduction}

Novel Coronavirus disease 2019 (COVID-19) is a virus originating from Wuhan, Hubei Province, China which has spread widely and rapidly in China and several other countries causing outbreaks of acute pneumonia infection [1]. WHO declared this virus a pandemic [2]. This virus has spread in 219 countries and territories worldwide with 125,121,573 confirmed cases and 2,750,559 deaths as of March 24, 2021 [3].

Although everyone is at risk of infection, pregnant women are a group that is more susceptible to infection [4]. The occurrence of physiological changes during pregnancy results in decreased partial immunity, so that it can have a serious impact on pregnant women. This is why pregnant women are made a vulnerable group at 
risk of being infected with COVID-19 [5]. Research conducted at an affiliated New York Hospital for 2 weeks from March 13, 2020 to March 27, 2020 found as many as 43 pregnant women who tested positive for Covid19, with 14 people without symptoms and 29 others with symptoms [6].

Almost all health services have been affected by this pandemic, both in terms of access and quality. Antenatal Care is one of the services affected by the COVID-19 pandemic. Antenatal care services that are carried out in a comprehensive, integrated and quality manner can detect early problems/diseases that may arise during pregnancy so that these problems/diseases can be treated early [7].

This COVID-19 pandemic situation increases the anxiety of pregnant women, not only worrying about the condition of the fetus but also worrying about whether the mother and fetus will be healthy free of COVID-19 infection, safe or not in pregnancy checks during the pandemic [8]. The results of the study by Corbett et al (2020) in the second and third trimesters of pregnant women found that $50.7 \%$ were often worried about their health during the COVID-19 pandemic. Some forms of concern include self-isolation, working from home, bulk purchases (food, hand sanitizer, toiletries, fuel and personal protection) [9].

The unpredictable future of this epidemic has been exacerbated by myths and misinformation, often fueled by misreported news and public misunderstandings about health messages, causing concern in the population [1]. Pregnancy accompanied by anxiety will lower the mother's immune system so that pregnant women will be more susceptible to being infected with COVID-19 [8].

Pregnant women are placed into a vulnerable group so that they need careful monitoring of their health [10]. The provision of maternal services during a pandemic needs to be a concern to avoid an increase in maternal morbidity and mortality, especially when there are restrictions on maternal health services. For example, pregnant women are reluctant to go to the Puskesmas or other health service facilities for fear of being infected, there are recommendations for postponing pregnancy check-ups and classes for pregnant women, as well as the unpreparedness of services in terms of personnel and infrastructure including personal protective equipment [8].

\section{Method}

This literature review was carried out by searching for literature from scientific publications spanning 2019-2021 using several databases, namely Pubmed, Wiley Online, Science Direct, and Google Scholar. In a search of the literature in this study, using the keywords Anxiety "OR" Pregnant Women "OR" Antenatal Care "OR" COVID-19, I found 14 articles filtered according to title, abstract, 2019-2021.

A search on Pubmed found 5 articles, then Science Direct found 3 articles, and on Google Scholar found 6 matching articles. However, in the final process of literature screening, all the articles that were found were readjusted to the inclusion criteria based on the title of the literature and after being read carefully, the results obtained were only 5 articles that matched the objects discussed in the literature review. The inclusion and exclusion criteria are as follows:

1. Inclusion Criteria

A. Research article on the level of anxiety of pregnant women towards Antenatal Care (ANC) visits during the COVID-19 pandemic

B. Publication between 2019-2021

C. Articles in Indonesian and English

D. Full text, journal articles, open access 
2. Exception Criteria

A. Articles other than Indonesian and English

B. Literature review articles, systematic reviews, RCT 


\section{Result}

\begin{tabular}{|c|c|c|c|c|c|c|}
\hline Number & Author & Research Title & Country & Method & Instrument & Result \\
\hline 1. & $\begin{array}{l}\text { Nining } \\
\text { Sulistyowati } \\
\text { and Yeti } \\
\text { Trisnawati }\end{array}$ & $\begin{array}{l}\text { Pregnant } \\
\text { Mother's } \\
\text { Anxiety Levels } \\
\text { on Antenatal } \\
\text { Care During } \\
\text { The COVID-19 } \\
\text { Pandemic }\end{array}$ & Indonesia & $\begin{array}{l}\text { Analytical } \\
\text { research } \\
\text { with cross } \\
\text { sectional } \\
\text { design }\end{array}$ & $\begin{array}{l}\text { Hamilton } \\
\text { Anxiety } \\
\text { Rating Scale } \\
\text { (HARS) } \\
\text { questionnaire }\end{array}$ & $\begin{array}{l}\text { ANC visits of pregnant } \\
\text { women to health care } \\
\text { facilities during the covid- } \\
19 \text { pandemic mostly } \\
\text { carried out regular ANC } \\
\text { visits } 22 \text { pregnant women } \\
(68.8 \%) \text {, pregnant women } \\
\text { did not experience anxiety } \\
9(28.1 \%) \text {. Pregnant } \\
\text { women who experience } \\
\text { anxiety and do not } \\
\text { regularly visit ANC as } \\
\text { many as } 12 \text { pregnant } \\
\text { women ( } 37.5 \%) \text {. Pregnant } \\
\text { women who do not } \\
\text { experience anxiety all } \\
\text { make regular ANC visits, } \\
\text { namely } 9 \text { respondents. }\end{array}$ \\
\hline 2. & $\begin{array}{l}\text { Kandace } \\
\text { Sianipar, } \\
\text { Juneris } \\
\text { Aritonang, } \\
\text { and Wilda } \\
\text { Wahyuni } \\
\text { Siregar }\end{array}$ & $\begin{array}{l}\text { The Anxiety of } \\
\text { Pregnant } \\
\text { Women About } \\
\text { Ante Natal Care } \\
\text { Services in The } \\
\text { Era of The } \\
\text { COVID-19 } \\
\text { Pandemic at The } \\
\text { Bandar } \\
\text { Khalipah Health } \\
\text { Center In } 2020\end{array}$ & Indonesia & $\begin{array}{l}\text { Descriptive } \\
\text { study }\end{array}$ & $\begin{array}{l}\text { Hamilton } \\
\text { Anxiety } \\
\text { Rating Scale } \\
\text { (HARS) } \\
\text { questionnaire }\end{array}$ & $\begin{array}{l}\text { The majority of } \\
\text { respondents had mild } \\
\text { anxiety (44\%) about Ante } \\
\text { Natal Care services in the } \\
\text { Covid-19 pandemic era. } \\
\text { From the results of this } \\
\text { study, pregnant women } \\
\text { should seek correct } \\
\text { information about safe } \\
\text { pregnancy during the } \\
\text { Covid-19 pandemic so that } \\
\text { they can change the } \\
\text { anxiety of pregnant } \\
\text { women about Ante Natal } \\
\text { Care services in the Covid- } \\
19 \text { pandemic era assisted } \\
\text { by health workers in health } \\
\text { education activities. }\end{array}$ \\
\hline 3. & $\begin{array}{l}\text { Mega Silvian } \\
\text { Natalia, and } \\
\text { Tutik Ekasari }\end{array}$ & $\begin{array}{l}\text { Anxiety In } \\
\text { Pregnant } \\
\text { Mothers On } \\
\text { ANC Visit In } \\
\text { The Era } \\
\text { COVID-19 } \\
\text { Pandemic }\end{array}$ & Indonesia & $\begin{array}{l}\text { Analytical } \\
\text { research } \\
\text { with cross } \\
\text { sectional } \\
\text { design }\end{array}$ & $\begin{array}{l}\text { Hamilton } \\
\text { Anxiety } \\
\text { Rating Scale } \\
\text { (HARS) } \\
\text { questionnaire }\end{array}$ & $\begin{array}{l}\text { The results of the } \\
\text { statistical test obtained a } \\
\text { value of } \mathrm{p}=0.011 \text { so that } \\
\text { it can be interpreted that } \\
\text { there is a relationship } \\
\text { between anxiety and ANC } \\
\text { visits in the era of the } \\
\text { covid } 19 \text { pandemic. }\end{array}$ \\
\hline
\end{tabular}




\begin{tabular}{|c|c|c|c|c|c|c|}
\hline 4. & H. Jiang et al. & $\begin{array}{l}\text { Maternal Mental } \\
\text { Health Status } \\
\text { and Approaches } \\
\text { for Accessing } \\
\text { Antenatal Care } \\
\text { Information } \\
\text { During the } \\
\text { COVID-19 } \\
\text { Epidemic in } \\
\text { China: Cross- } \\
\text { Sectional Study }\end{array}$ & China & $\begin{array}{l}\text { Cross } \\
\text { Sectional } \\
\text { Study }\end{array}$ & $\begin{array}{l}\text { Self-Rating } \\
\text { Anxiety Scale } \\
\text { (SAS) }\end{array}$ & $\begin{array}{l}\text { The prevalence of } \\
\text { perceived stress, anxiety, } \\
\text { and depression among } \\
\text { these participants was } \\
89.1 \%(1668 / 1873 ; 95 \% \\
\text { CI } 87.6 \%, 90.4 \%), 18.1 \% \\
(339 / 1873 ; 95 \% \text { CI } 16.4 \% \text {, } \\
19.9 \%) \text {, and } 45.9 \% \\
(859 / 1873 ; 95 \% \text { CI } 43.6 \% \text {, } \\
48.1 \%), \text { respectively. } \\
\text { Hospitals' official } \\
\text { accounts on the Chinese } \\
\text { social media platforms } \\
\text { WeChat and Weibo were } \\
\text { the most popular channels } \\
\text { among these pregnant } \\
\text { women to obtain antenatal } \\
\text { care information during } \\
\text { the COVID-19 outbreak. } \\
\text { Access to antenatal care } \\
\text { information via the } \\
\text { hospitals' official social } \\
\text { media accounts was found } \\
\text { to be associated with a } \\
\text { significantly lower risk of } \\
\text { perceived stress (adjusted } \\
\text { odds ratio Access to health } \\
\text { care information via } \\
\text { hospital hotlines or SMS } \\
\text { was found to be } \\
\text { significantly associated } \\
\text { with a lower risk of } \\
\text { anxiety only. }\end{array}$ \\
\hline 5. & & $\begin{array}{l}\text { Antenatal } \\
\text { depression and } \\
\text { anxiety during } \\
\text { the COVID-19 } \\
\text { pandemic: a } \\
\text { cross-sectional } \\
\text { study in } \\
\text { pregnant women } \\
\text { from routine } \\
\text { health care } \\
\text { contact in } \\
\text { Greece }\end{array}$ & Yunani & $\begin{array}{l}\text { Cross } \\
\text { Sectional } \\
\text { Study }\end{array}$ & $\begin{array}{l}\text { State -Trait } \\
\text { Anxiety } \\
\text { Inventory } \\
\text { (STAI) }\end{array}$ & $\begin{array}{l}\text { The prevalence of } \\
\text { antenatal depression } \\
\text { (EPDS score } \geq 13 \text { ) in the } \\
\text { population of the study } \\
\text { was } 13.5 \% \text { and antenatal } \\
\text { anxiety (OR: } 5.074 ; 95 \% \\
\text { CI: } 2.898-8.883 \text { ) increased } \\
\text { the risk of antenatal } \\
\text { depression during the } \\
\text { COVID-19 pandemic. The } \\
\text { State-anxiety score } \\
\text { (median) was significantly } \\
\text { higher than the Trait- } \\
\text { anxiety (median) (41 vs. } \\
36 ; p<0.001 \text { ), revealing an } \\
\text { increase in the levels of } \\
\text { anxiety in the pandemic. }\end{array}$ \\
\hline
\end{tabular}




\section{Discussions}

Based on the search results, found 3 articles that match the inclusion criteria. The selected study relates to the level of anxiety of pregnant women towards Antenatal Care (ANC) services during the COVID-19 pandemic. Based on the results of the review of the 3 articles, they are discussed in the discussion below.

\subsection{Characteristics of mother}

Almost all pregnant women who became respondents, including those of healthy reproductive age, were aged 20-35 years. At this age the reproductive system is very well-developed. Meanwhile, those aged less than 20 years and more than 35 years increase various risks of pregnancy such as miscarriage, bleeding which is one of the causes of maternal death, and low quality of pregnancy outcomes [11].

There is a significant relationship between age and anxiety. Maternal age greatly determines maternal health because it is related to anatomical and physiological conditions during pregnancy, childbirth and the puerperium. In addition to anatomy, psychologically, adult mothers are able to solve the problems they face calmly, especially in dealing with pregnancy, childbirth, and postpartum [12].

Maternal education has positive distribution of anxiety experienced by pregnant women during the COVID-19 pandemic. The education of pregnant women plays a very important role in forming reasoning related to solving and handling the COVID-19 outbreak so that it does not cause risky anxiety [13]. Anxiety in pregnant women tends to be found in pregnant women with low education. This is due to the inability to understand in analyzing a COVID-19 incident so that their perception is formed with a fearful response [14].

There is a difference in anxiety between working and non-working mothers. The majority of working mothers experience anxiety [15]. The anxiety of working people tends to be caused by the workload and household matters. While mothers who do not work tend to have a lighter mind than those who work [16].

Primigravida pregnant women will usually experience anxiety and will increase as the gestational age increases and the delivery schedule gets closer. Previous experience of giving birth to multigravida pregnant women allows mothers to minimize the anxiety that arises either due to pregnancy or due to other factors [11].

\subsection{Anxiety Level}

According to Prawirohardjo (2014), anxiety is a form of individual emotion related to a sense of being threatened by something, usually with a woven object that is not very clear. Anxiety with a reasonable intensity can be considered to have a positive value as motivation, but if the intensity is very strong and negative, it will cause harm and can interfere with the physical and psychological state of the individual concerned [18].

Anxiety is the most common emotional problem in pregnancy. The majority of pregnant women experience mild anxiety [19][8]. The COVID-19 pandemic has increased anxiety, but not increased rates of depression in pregnant women in Greece [20]. In China, pregnant women experience perceived high levels of stress, anxiety, and depression during the COVID-19 outbreak [21]. Anxiety in pregnant women can affect pregnancy such as preterm delivery, stunted fetal growth, and poor neurodevelopment and 
behavior [18]. This shows that the anxiety of pregnant women, including during the COVID-19 pandemic, needs to be handled appropriately so as not to interfere with her pregnancy.

There is a relationship between the level of anxiety of pregnant women and Antenatal Care visits to health care facilities during the COVID-19 pandemic [19][22]. Anxiety of pregnant women in conducting Antenatal Care visits during the COVID-19 pandemic, both face-to-face and online, psychological assessment of pregnant women is very necessary and can be carried out optimally, so that problems related to anxiety can be immediately overcome and will not hinder Antenatal Care visits to check the well-being of mother and baby [22].

Pregnancy consultations can be done online or by telephone so that pregnancy checks can still be done to see the development of the baby. This is done as an effort so that Antenatal Care services are still fulfilled so that the mother and fetus remain in a healthy condition despite the COVID-19 pandemic.

\section{Conclusion}

The majority of pregnant women experience mild anxiety. The COVID-19 pandemic has increased anxiety among pregnant women. There is a relationship between the level of anxiety of pregnant women and Antenatal Care visits to health care facilities during the COVID-19 pandemic. Psychological assessment of pregnant women is very necessary and can be carried out optimally so that problems related to anxiety can be overcome immediately and will not hinder Antenatal Care visits.

\section{Acknowledgements}

The researcher would like to thank the supervisors who have guided me in the research and preparation of this article.

\section{References}

[1] Y. Bao, Y. Sun, S. Meng, J. Shi, and L. Lu, "2019-nCoV epidemic: address mental health care to empower society," The Lancet, vol. 395, no. 10224. Lancet Publishing Group, pp. e37-e38, Feb. 22, 2020, doi: 10.1016/S0140-6736(20)30309-3.

[2] World Health Organization, “Coronavirus disease 2019 (COVID-19) Situation Report-63,” Mar. 2020. Accessed: Mar. 25, 2021. [Online]. Available: https://www.who.int/docs/default-source/coronaviruse/situation-reports/20200323-sitrep-63-covid19.pdf?sfvrsn=d97cb6dd_2.

[3] Worldmeter, "Countries where Coronavirus has spread," 2021. https:/www.worldometers.info/coronavirus/countries-wherecoronavirus-has-spread/ (accessed Mar. 25, 2021).

[4] F. R. Fakari and M. Simbar, "Coronavirus pandemic and worries during pregnancy; a letter to editor," Arch. Acad. Emerg. Med., vol. 8, no. 1, pp. e21-e21, 2020.

[5] H. Liang and G. Acharya, "Novel corona virus disease (COVID-19) in pregnancy: What clinical recommendations to follow?," 2020 .

[6] N. Breslin et al., "Coronavirus disease 2019 infection among asymptomatic and symptomatic pregnant women: two weeks of confirmed presentations to an affiliated pair of New York City hospitals,” Am. J. Obstet. Gynecol. MFM, vol. 2, no. 2, p. 100118, 2020, doi: 10.1016/j.ajogmf.2020.100118.

[7] A. I. Rachmawati, R. D. Puspitasari, and E. Cania, "Faktor-faktor yang Memengaruhi Kunjungan Antenatal Care ( ANC ) Ibu Hamil," Majority, vol. 7, no. November, pp. 72-76, 2017.

[8] K. Sianipar, J. Aritonang, and W. W. Siregar, "Kecemasan Ibu Hamil Tentang Pelayanan Antenatal Care di Era Pandemi COVID-19," vol. 6, no. 1, pp. 28-31, Jul. 2021, doi: 10.51544/jkmlh.v6i1.1962.

[9] G. A. Corbett, S. J. Milne, M. P. Hehir, S. W. Lindow, and M. P. O'connell, "Health anxiety and behavioural changes of pregnant women during the COVID-19 pandemic,” Eur. J. Obstet. Gynecol. Reprod. Biol., vol. 249, no. 5, pp. 96-97, Jun. 2020, doi: 10.1016/j.ejogrb.2020.04.022. 
[10] S. E. Adeigbe, "Impact Of Covid 19 On Antenatal Care Povision,” Europenia Journal Of Midwifery, Apr. 16, 2020. http://www.europeanjournalofmidwifery.eu/Impact-of-COVID-19-on-antenatal-care-provision,121096,0,2.html (accessed Mar. 26, 2021).

[11] Islami, Nasriyah, and N. Asiyah, "Perbedaan Skor Kecemasan Ibu Hamil Selama Pandemi,” J. Ilmu Keperawatan dan Kebidanan, vol. 12, no. 1, p. 164, 2021, doi: 10.26751/jikk.v12i1.924.

[12] A. D. Citra Dewi, M. Nurbaiti, R. Surahmat, and Putinah, "Kecemasan pada Ibu Hamil di Masa Pandemi Covid 19 di RSUD Ibnu Sutowo Baturaja,” J. Smart Keperawatan, vol. 8, no. 1, pp. 64-69, 2021, doi: 10.34310/jskp.v8i1.452.

[13] Muzayyana and S. N. H. Saleh, "Jurnal Keperawatan Muhammadiyah Bengkulu," J. Keperawatan Muhammadiyah, vol. 6, no. $3,2021$.

[14] A. Hafid and H. Hasrul, "Hubungan Kejadian Pandemi Covid 19 Dengan Kecemasan Ibu Hamil Trimester Tiga,” J. Keperawatan Muhammadiyah, vol. 6, no. 2, 2021.

[15] D. Hendriani, H. P. Widyastuti, R. A. Putri, and R. Puspitaningsih, "Peran Suami Dalam Gangguan Kecemasan dan Stress pada Ibu Hamil Selama Pandemi COVID-19,” MMJ (Mahakam Midwifery Journal), vol. 6, no. 1, pp. 28-36, 2021.

[16] C. D. Y. Nekada, T. A. E. Amigo, and P. D. Krisnanto, "Terap Bekerja di Tengah Kecemasan Terhadap Pandemi COVID-19," in Prosiding Seminar Nasional Multidisiplin Ilmu, 2020, vol. 2, no. 1, pp. 158-165.

[17] S. Prawirohardjo, Ilmu Kebidanan, 4th ed. Jakarta: PT Bina Pustaka Sarwono Prawirohardjo, 2014.

[18] Verawati, A. Meiranny, and A. Rahmawati, "Hubungan Pengetahuan tentang Covid-19 terhadap Kecemasan Ibu Hamil Trimester III The Relationship of Knowledge about COVID-19 to Third Trimester Pregnant Women 's Anxiety,” vol. 12, pp. 234-241, 2021.

[19] N. Sulistyowati and Y. Trisnawati, "Tngkat Kecemasan Ibu Hamil Terhadap Kunjungan Antenatal Care di Masa Pandemi COVID-19,” J. Kebidanan, vol. 13, no. 01, pp. 96-103, Jun. 2021, Accessed: Dec. 08, 2021. [Online]. Available: http://ejurnal.stikeseub.ac.id/index.php/jkeb/article/view/423.

[20] I. Tsakiridis, T. Dagklis, A. Mamopoulos, A. Athanasiadis, R. Pearson, and G. Papazisis, "Antenatal depression and anxiety during the COVID-19 pandemic: a cross-sectional study in pregnant women from routine health care contact in Greece," J. Perinat. Med., 2021, doi: doi:10.1515/jpm-2020-0473.

[21] H. Jiang et al., "Maternal Mental Health Status and Approaches for Accessing Antenatal Care Information During the COVID19 Epidemic in China: Cross-Sectional Study,” J Med Internet Res, vol. 23, no. 1, p. e18722, 2021, doi: 10.2196/18722.

[22] M. S. Natalia and T. Ekasari, "Kecemasan Pada Ibu Hamil Terhadap Kunjungan ANC di Era Pandemi COVID-19," J. Ilm. Kebidanan (Scientific J. Midwifery), vol. 7, no. 2, pp. 130-134, 2021, Accessed: Dec. 08, 2021. [Online]. Available: http://www.journal.stikespemkabjombang.ac.id/index.php/jikeb/article/view/828/575. 